\title{
Accounting
}

\section{The quality of audit services: An assessment from FDI clients in Vietnam}

\section{Thi Thu Thuy Lai ${ }^{*}$ and Duc Hieu Phama}

\begin{tabular}{l}
${ }^{a}$ Thuongmai University, Vietnam \\
\hline C H R O N I C L E \\
\hline Article history: \\
Received May 152020 \\
Received in revised format May \\
162020 \\
Accepted July 62020 \\
Available online \\
July 122020 \\
\hline Keywords: \\
Auditing \\
Quality of service \\
Factors affecting FDI enterprises \\
Vietnam \\
\hline
\end{tabular}

\section{A B S T R A C T}

\begin{abstract}
This study was conducted to investigate the determinants affecting the quality of audit services in Vietnam, from the perspective of auditing clients - the Foreign Direct Investment (FDI) clients. Based on the adjustments of SERVQUAL model, the article has discovered five out of six factors that positively affect audit service quality of historical financial statements at FDI enterprises in Vietnam, namely: tangibles, reliability, responsiveness, assurance and non-audit services. Data used in the study was collected from 250 accountants and directors at FDI enterprises in Vietnam. The Exploratory factor analysis (EFA) and Linear regression model were used to identify the factors that affect the quality of audit services. Findings from empirical research are the basis for recommendations for audit firms to enhance the quality of audit services in Vietnam.
\end{abstract}

\section{Introduction}

Audit is a service and audit service quality is defined as the "quality of the input provided by the audit firm while performing the audit services" (Pandit, 1999, p. 173). That is, "quality occurs during service delivery, usually in an interaction between the client and the contact person from the service firm" (Parasuraman et al., 1985, p. 42, cited in Pandit, 1999, p. 173). Audit quality, however, is difficult to observe directly (Shockley, 1982; Francis, 2004); consequently one approach for assessing quality is to examine the perceptions of audit service quality held by clients and customers as users of financial statements and the audit opinion (Schroeder et al., 1986; Carcello et al., 1992; Nguyen et al., 2020; Davis, 1995; Behn et al., 1997; Warming-Rasmussen \& Jensen, 1998). Zeithaml and Bitner (2000, p. 81) state that service quality is "a critical component of customer perceptions", while Warming-Rasmussen and Jensen (1998, p. 65) argue that "there is an increasing recognition in audit research that the only definition of quality is the customers". This study examines the audit services quality attributes that are perceived to be important in evaluating the quality of audit services and in determining satisfaction with audit services quality of auditing firms in Vietnam. Therefore, three main points will be studied in detail:

i. Synthesize the literature on audit services quality.

ii. Develop a research framework for studying the factors that affect the audit services quality in Vietnam.

iii. Do empirical study to determine the impact of factors on the audit services quality in Vietnam from clients' perspective (FDI enterprises)

\section{Literature Review}

\subsection{Audit Services Quality}

Service quality and its effect on business development have been studied in a wide range of other areas (Finn \& Lamb, 1991; Kettinger \& Lee, 1995) and are generally determined as a gap between performance and expectations (Parasuraman, Zeithaml

* Corresponding author.

E-mail address: $\underline{\text { laithuy@tmu.edu.vn }(T . T . T . ~ L a i)}$

(C) 2020 by the authors; licensee Growing Science, Canada doi: 10.5267/j.ac.2020.7.012 
\& Berry, 1988). Service quality is defined as the "quality occurs during service delivery, usually in an interaction between the client and the contact person from the service firm" (Parasuraman et al., 1985, p. 42, cited in Pandit, 1999, p. 173). A growing area of market research has linked clients' perceptions of service quality and customer satisfaction to intentions to repurchase a service from the same supplier (Oliver, 1980; Nguyen \& Do, 2020; Bitner, 1990; Cronin \& Taylor, 1992; Patterson, 1993; Taylor \& Baker, 1994; Zeithaml, Berry \& Parasuraman, 1996). Clients of audit firms have difficulty in directly assessing traditional concepts of audit quality (competence and independence) due to the complexity of the techniques and the associated proprietary methodologies or standardized methods of approach which are used by such firms. Intangibility and technical complexity of the services offered have therefore been assumed to lead clients to identify and base their assessments of the value of a firm on surrogate indicators such as, for example, corporate image (brand name), audit firm size (DeAngelo, 1981), audit firm industry specialization (Craswell, Francis \& Taylor 1996; Tran, 2020), office ambience, internal decor and support staff performance. In the study of audit quality in relation to customer satisfaction, Behn et al. (1997) relate the client overall satisfaction with external audit work to audit quality attributes based on the evaluation made by company controllers. The study finds that the client satisfaction is significantly related to certain audit quality attributes, which underlying components of audit quality include responsiveness to client needs, executive involvement, effectiveness and ongoing interaction with the audit committee, conduct of field works, industry expertise, and prior experience with the clients. Results indicate the important role of communication and relationships in promoting client satisfaction.

\subsection{Audit Services Quality Attributes}

In the consumer behavior theory, service quality is defined as the difference between customer expectations of service and perceived service offered by firms (SERVQUAL), and indicated five service quality dimensions (Parasuraman et al., 1988). SERVQUAL model developed by Parasuraman et al. $(1994,1991,1990,1988,1986,1985)$ is the most often used approach for measuring service quality and has compared customers' expectations before a service encounter and their perceptions of the actual service delivered (Parasuraman et al., 1985; Lewis and Booms, 1983; Gronroos, 1982). The SERVQUAL instrument with five dimensions; tangibles, reliability, responsiveness, assurance, and empathy (Zeithaml et al., 1990) measure customer service quality. The association between client satisfaction and audit quality attributes has been given little emphasis in previous research. Of these Carcello et al, (1992) created a questionnaire based on 41 audit quality attributes based on a literature review. This questionnaire was administered to the three groups of financial statement preparers, financial statement users and audit partners in the US. Exploratory factor analysis (EFA) - a statistical data reduction technique explained in greater detail in chapter five - reduced these 41 audit quality attributes to 12 audit quality factors. The five most important quality factors were: (i) team experience with client; (ii) industry expertise;(iii) an audit team that operates to high ethical standards; (iv) a partner knowledge able about the client's industry; and (v) frequent communication between auditors and management. Behn et al. (1997) examined the relationship among client satisfaction in terms of audit team and audit firm, 12 attributes of audit quality, auditor change, and controller work experience. The authors' results indicated a significant, positive relationship between some important audit quality attributes (i.e. responsiveness to client needs, executive involvement, effective and ongoing interaction with the audit committee, conduct of field work, industry expertise, and prior experience) and client satisfaction. On the other hand, five factors (i.e. technical competence, independence, due care, quality commitments, and ethical standards) had no significant relationship with client satisfaction. The authors justified the failure of these five factors in contributing to client satisfaction in that clients expect that all audit firms have already worked along these five factors and need no evidence to prove their contribution to audit satisfaction. Saxby et al. (2004) examined the relationship between financial services quality (i.e. audit, consulting, tax and financial statement preparation) and client satisfaction. The authors focused mainly on those services provided by CPA firms. Among the five dimensions of service quality (i.e. tangibles, reliability, responsiveness, assurance and empathy), only two dimensions (i.e. reliability and assurance) were found to be positively associated with clients' satisfaction. According to Duff (2004), audit quality is a multi-dimensional construct and is made up of both service quality issues and the need to deliver technical quality. Service quality includes responsiveness, provision of non-auditing services, empathy and client services. Technical quality usually conceptualized as the competence and objectivity of the auditor is described by reputation, capability, independence, expertise and experience. Samelson et al. (2006) focused on the auditing profession in public sector to identify the main audit quality attributes that may associate with client satisfaction. Findings of authors indicated that auditor expertise, responsiveness, executive involvement and fieldwork conducting are the main quality attributes that significantly contribute to client satisfaction. More important, authors' findings proved that the effectiveness of these attributes not different between public and private sector. Butcher et al. (2013) performed a study to assess the relationship between the audit quality attributes and the auditor retention. Focused on Australian state of New South Wales as there was prior research evidence on the satisfaction with audit service quality, the authors used 48 audit attributes to measure the audit quality. The 48 attributes were distributed over 7 categories include reputation, capability, assurance, independence, expertise, experience and responsiveness. Authors' findings indicated that only expertise and responsiveness to client needs are significantly associated with auditor retention. Despite the results of the above mentioned studies are different from one country to another in terms of the relationship between audit quality attributes and client satisfaction; there is some consensus on the role of audit quality attribute in enhancing the client satisfaction. 


\section{Research model and hypothesis development}

Based on the SERVQUAL model adjustment, the integrated model to study the factors affecting audit services quality in Vietnam will be developed as follows (Fig. 1)

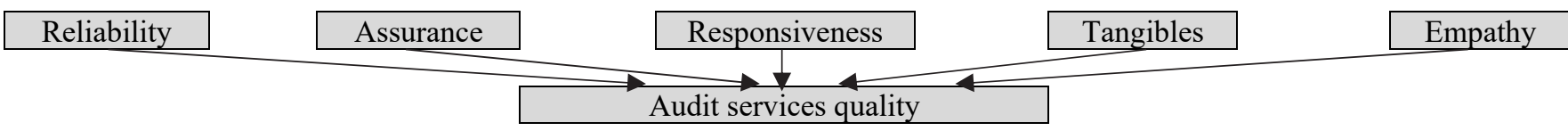

Fig. 1. Proposal model for audit services quality in Vietnam

\section{Research Hypotheses}

From the proposed research model, the following hypotheses are presented:

$\mathrm{H}_{1}$ : There is a positive relationship between the Tangibles and Audit services quality.

$\mathrm{H}_{2}$ : There is a positive relationship between Reliability and Audit services quality.

$\mathrm{H}_{3}$ : There is a positive relationship between Responsiveness and Audit services quality.

$\mathrm{H}_{4}$ : There is a positive relationship between Assurance and Audit services quality.

$\mathrm{H}_{5}$ : There is a positive relationship between Empathy and Audit services quality.

$\mathrm{H}_{6}$ : There is a positive relationship between Non-Audit Service and Audit services quality.

\section{Research Methodology}

\subsection{Variables and scales}

Variables are aggregated according to the factors and coded in Table 1. The variables are aggregated by reference factors from previous studies, including: the dependent variable (CLDV) is measured by 3 items and the independent variables: Tangible (PTHH) is measured by 4 items, Reliability (TCKH) is measured by 4 items, Responsiveness (DUKH) is measured by 4 items, Assurance (NLPV) is measured by 5 items, Empathy (CTKH) is measured by 3 items and Non-Audit Service (PKT) is measured by 3 items

The scale was a five-point Likert-type scale ranging from strongly disagree (1) to strongly agree (5).

\section{Table 1}

Observed variables

\begin{tabular}{|c|c|c|}
\hline No. & Coding & Indicators \\
\hline \multicolumn{3}{|c|}{ 1. Tangible } \\
\hline 1 & PTHH1 & The equipment and tools at the audit firm are very modern \\
\hline 2 & PTHH2 & The staff of the audit firm have neat and polite costumes \\
\hline 3 & PTHH3 & Audit firm is fully equipped with material facilities in service activities (laptop, USB $3 G, .$. ) \\
\hline 4 & PTHH4 & Reports and other documents of the audit firm are presented professionally, scientifically and beautifully \\
\hline \multicolumn{3}{|r|}{ - } \\
\hline 5 & TCKH1 & Audit firm always perform the jobs on the agreed time \\
\hline 6 & TCKH2 & Auditors guide audit clients fully, in detail on audit regulations and procedures \\
\hline 7 & TCKH3 & Audit firm always perform confidentiality of audited information at the highest level \\
\hline 8 & TCKH4 & Audit firm is reputable in the field of auditing \\
\hline \multicolumn{3}{|c|}{ 3. Responsiveness } \\
\hline 9 & DUKH1 & Auditees can contact the auditor easily and quickly \\
\hline 10 & DUKH2 & Audit firm may provide accounting procedures within an acceptable framework for economic transactions that produce the desired customer results \\
\hline 11 & DUKH3 & Auditors are always available to provide accounting instructions to the clients \\
\hline 12 & DUKH4 & Audit firm often discover problems that create added value for the clients \\
\hline \multicolumn{3}{|r|}{ (2) } \\
\hline 13 & NLPV1 & The audit team directly performs the audit with a high level of knowledge, competence and understanding \\
\hline 14 & NLPV2 & The direct audit team conducts an audit that is experienced, mature and communicates well \\
\hline 15 & NLPV3 & The direct audit team conducts an audit that is capable of communicating, interpreting and convincing matters \\
\hline 16 & NLPV4 & The audit firm has senior personnel with deep expertise, high education and broad understanding \\
\hline 17 & NLPV5 & The audit firm has sufficient size, expertise and personnel to provide other relevant needs when the client needs it \\
\hline \multicolumn{3}{|r|}{ 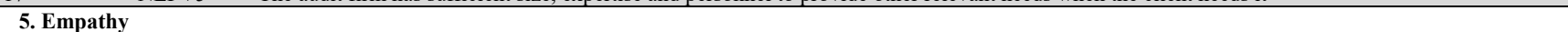 } \\
\hline 18 & CTKH1 & Auditors are ready to listen to customers' opinions \\
\hline 19 & CTKH2 & Auditors often actively ask, exchange and guide the legal provisions related to the audit for customers \\
\hline 20 & СТКH3 & Auditors are interested in other matters of customers in addition to audit issues \\
\hline \multicolumn{3}{|c|}{ 6. Non-Audit Service } \\
\hline 21 & PKT1 & Audit firm provides accounting consulting services to clients \\
\hline 22 & PKT2 & Audit firm provides tax advisory services to clients \\
\hline 23 & PKT3 & Audit firm provides legal advice to clients \\
\hline \multicolumn{3}{|c|}{ 7. Audit service quality } \\
\hline 24 & CLDV1 & In general, you are satisfied with the quality of audit services provided by the audit firm \\
\hline 25 & CLDV2 & Your company will continue to use audit services provided by independent audit firms in Vietnam \\
\hline 26 & CLDV3 & You will introduce to friends and relatives about the audit services performed by independent audit firms in Vietnam \\
\hline
\end{tabular}




\subsection{Sample selection and data collection}

According to Hair et al. (2006), the sample size must be at least 100. Hoang Trong and Chu Nguyen Mong Ngoc (2008) set the sample size by 5 times of the number of observation variables. Accordingly, with 26 observation variables, the minimum sample size is $26 \times 5=130$. According to Gorsuch (1983), the sample size must be at least 200. For the sake of reliability, 250 questionnaires were sent to the respondents via the Google Document Tool. Amongst 232 responses, 15 were rejected for invalid reasons. Therefore, the remaining number in the analysis was 217 , of which $44.2 \%$ were males, $46.1 \%$ were the accounting managers from FDI enterprises in Vietnam.

\section{Result and Discussion}

\subsection{Scale reliability}

To determine the reliability of scale, Cronbach's alpha was employed. In general, variables with a Corrected Item-Total Correlation greater than 0.3 and a Cronbach's Alpha coefficient of 0.6 or more are considered acceptable and analyzed in the next steps (Nunnally \& Burnstein, 1994). Cronbach's Alpha coefficients are shown in Table 2

\section{Table 2}

Cronbach's Alpha coefficient

\begin{tabular}{|c|c|c|c|c|c|}
\hline Factors & Cronbach's Alpha & $\mathrm{N}$ & Factors & Cronbach's Alpha & $\mathrm{N}$ \\
\hline Tangibles (PTHH) & 0.825 & 4 & Empathy (CTKH) & 0.653 & 3 \\
\hline Reliability (TCKH) & 0.743 & 4 & Non-Audit Service (PKT) & 0.847 & 3 \\
\hline Responsiveness (DUKH) & 0.654 & 4 & Audit services quality (CLDV) & 0.673 & 3 \\
\hline Assurance (NLPV) & 0.830 & 5 & \multicolumn{3}{|c|}{ Source: SPSS 20.0} \\
\hline
\end{tabular}

The reliability of the determinants in the study model shows that all determinants included in the model are reliable, the Cronbach's Alpha coefficient is greater than 0.6, the coefficient of variation is greater 0.3 . This shows that the research concepts constructed from the observational variables are of internal consistency and are well-measured concepts

\subsection{Exploratory Factor Analysis}

Table 3 shows that all conditions for the Exploratory Factor Analysis (EFA) are met with KMO $=0.737$ and the Bartlett's sig. $=0.000$, indicating that the EFA model is suitable. The results from Principal Component and Varimax show 21 variables load quite strongly to each factor with absolute value of loadings is greater than 0.5 . The remaining 2 variables have factors loadings smaller than 0.5 will be excluded. The 21 variables are then analyzed using EFA and 6 generated components are extracted from the analysis with total variances in the dataset $69.027 \%$

\section{Table 3}

KMO and Bartlett's Test

\begin{tabular}{lll}
\hline Kaiser-Meyer-Olkin Measure of Sampling Adequacy. & & $\mathbf{. 7 3 7}$ \\
Bartlett's Test of Sphericity & Approx. Chi-Square & 1896.243 \\
& df & 210 \\
& Sig. & $\mathbf{0 0 0}$ \\
\hline
\end{tabular}

\section{Table 4}

Rotated Component Matrix ${ }^{\mathrm{a}}(2$ times)

\begin{tabular}{|c|c|c|c|c|c|c|}
\hline & \multicolumn{6}{|c|}{ Component } \\
\hline & 1 & 2 & 3 & 4 & 5 & 6 \\
\hline NLPV4 & .890 & & & & & \\
\hline NLPV3 & .849 & & & & & \\
\hline NLPV2 & .818 & & & & & \\
\hline NLPV1 & .799 & & & & & \\
\hline PTHH4 & & .866 & & & & \\
\hline РTHH3 & & .829 & & & & \\
\hline РTHH2 & & .780 & & & & \\
\hline PTHH1 & & .740 & & & & \\
\hline CTKH1 & & & .872 & & & \\
\hline DUKH3 & & & .745 & & & \\
\hline DUKH2 & & & .703 & & & \\
\hline DUKH1 & & & .677 & & & \\
\hline PKT3 & & & & .885 & & \\
\hline PKT1 & & & & .877 & & \\
\hline PKT2 & & & & .828 & & \\
\hline TCKH2 & & & & & .798 & \\
\hline ТCКH3 & & & & & .788 & \\
\hline TCKH4 & & & & & .723 & \\
\hline TCKH1 & & & & & .669 & \\
\hline CTKH3 & & & & & & .881 \\
\hline CTKH2 & & & & & & .725 \\
\hline
\end{tabular}


As a result, through the EFA, there are 6 components representing the factors affecting the audit quality with 21 variables.

\subsection{Linear Regression Analysis}

Based on the adjusted model after EFA, linear regression results are presented as follows:

$$
C L D V=\beta_{0}+\beta_{1} N L P V+\beta_{2} P T H H+\beta_{3} D U K H+\beta_{4} P K T+\beta_{5} T C K H+\beta_{6} C T K H+\varepsilon
$$

$\checkmark$ Dependent Variable: Audit services quality (CLDV).

$\checkmark$ Predictors: Tangibles (PTHH), Reliability (TCKH), Responsiveness (DUKH), Assurance (NLPV), Empathy (CTKH), Non-Audit Service (PKT)

Table 5

Model Summary

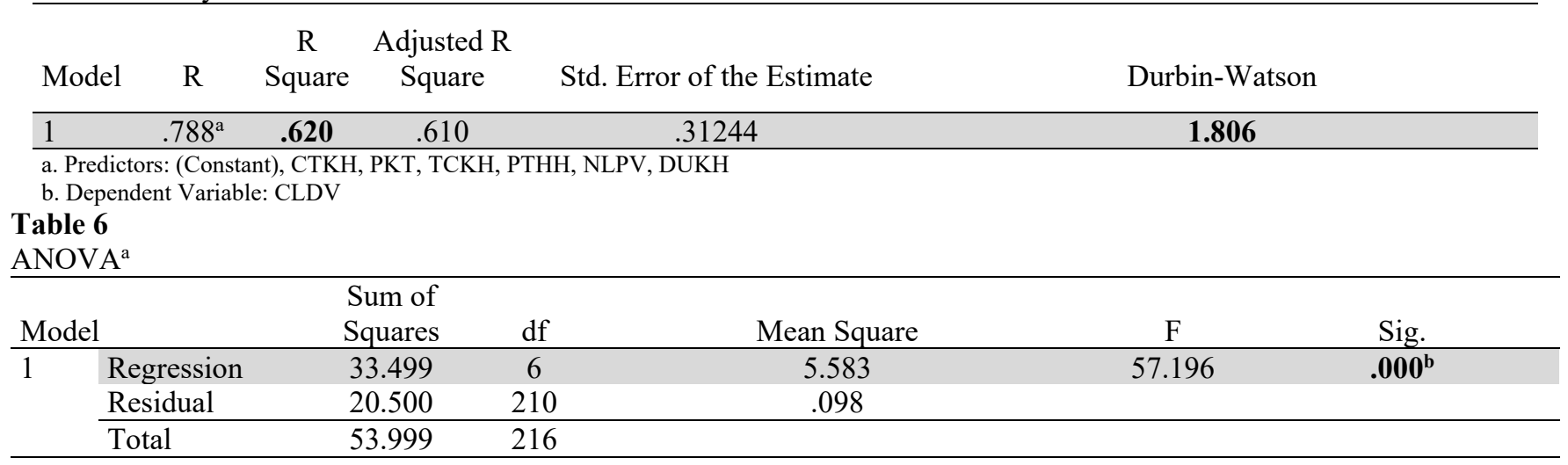

a. Dependent Variable: CLDV

b. Predictors: (Constant), CTKH, PKT, TCKH, PTHH, NLPV, DUKH

Table 7

The results of regression analysis

\begin{tabular}{|c|c|c|c|c|c|c|c|c|c|}
\hline & & \multicolumn{2}{|c|}{$\begin{array}{c}\text { Unstandardized } \\
\text { Coefficients }\end{array}$} & \multirow{2}{*}{$\begin{array}{c}\text { Standardized } \\
\text { Coefficients } \\
\text { Beta } \\
\end{array}$} & \multirow[b]{2}{*}{$\mathrm{t}$} & \multirow[b]{2}{*}{ Sig. } & & \multicolumn{2}{|c|}{ Collinearity Statistics } \\
\hline \multicolumn{2}{|c|}{ Model } & $\mathrm{B}$ & Std. Error & & & & & Tolerance & VIF \\
\hline 1 & (Constant) & .284 & .202 & & 1.404 & & .162 & & \\
\hline & NLPV & .174 & .017 & .478 & 10.433 & & .000 & .862 & 1.160 \\
\hline & PTHH & .126 & .023 & .242 & 5.599 & & .000 & .970 & 1.031 \\
\hline & DUKH & .321 & .029 & .546 & 11.169 & & .000 & .756 & 1.323 \\
\hline & PKT & .088 & .016 & .240 & 5.438 & & .000 & .930 & 1.075 \\
\hline & TCKH & .248 & .030 & .356 & 8.168 & & .000 & .949 & 1.054 \\
\hline & CTKH & .029 & .024 & .055 & 1.171 & & .243 & .812 & 1.232 \\
\hline
\end{tabular}

From the above results, it can be seen that:

Multi-collinearity testing: The VIF of all independent variables is less than 10 , so the multi-collinearity in the model is considered not to be serious.

The Durbin Watson Test is a measure of autocorrelation (also called serial correlation) in residuals from regression analysis. The Durbin-Watson value is 1.806 (between 1 and 3). Model does not have autocorrelation. Result of ANOVA test with Sig. = 0.000 shows that the linear regression model was constructed in accordance with the dataset and was usable. The $\mathrm{R}^{2}(\mathrm{R}$ Square) $=0.620$ means that $62.0 \%$ of the variation in the audit services quality in Vietnam will be explained by factors with independent variables in the research model. Results of regression analysis indicate that independent variables including NLPV, PTHH, DUKH, PKT, TCKH are statistically significant (Sig. <5\%) to CLDV. Thus, the research hypotheses H1, H2, H3, H4, H6 are accepted. However, with the data collected, we do not find significant effect of CTKH on CLDV (Sig.> 5\%). Therefore, the research hypotheses $\mathrm{H} 5$ are rejected.

Standardized regression equations are as follows:

$$
C L D V=0.478 N L P V+0.242 P T H H+0.546 D U K H+0.240 P K T+0.356 T C K H
$$




\section{Conclusion}

This study focused on the factors that affect the audit services quality in Vietnam. The empirical research found out five key factors affecting the audit quality, namely: Tangibles, Reliability, Responsiveness, Assurance, and Non-Audit Service. The findings of the research provide recommendations for auditors and auditing firms to improve quality of assurance services provided by emphasizing on Responsiveness (DUKH with $\beta=0.546$ ), Assurance (NLPV with $\beta=0.479$ ), Reliability (TCKH with $\beta=0.356$ ), Tangibles (PTHH with $\beta=0.242$ ), Non-Audit Service (PKT with $\beta=0.240$ ).

\section{References}

Behn, B.K., Carcello, J.V., Hermanson, D.R., \& Hermanson, R.H. (1999), "Client satisfaction and Big 6 audit fees", Contemporary Accounting Research, 16(4), 587-608

Behn, B.K., Carcello, J.V., Hermanson, D.R., \& Hermanson, R.H. (1997). The determinants of audit client satisfaction among clients of Big 6 firms. Accounting Horizons, 11, 7-24

Butcher, K., Harrison, G. \& Ross, P. (2013). Perceptions of audit service quality and auditor retention. International Journal of Auditing, 17(1), 54-74.

Carcello, J.V., Hermanson, R.H., \& McGrath, N.T. (1992). Audit quality attributes: the perceptions of audit partners, preparers and financial statement users. Auditing: A Journal of Practice \& Theory, 11(1), 1-15

Craswell, A.T., Francis, J.R., \& Taylor, S.L. (1995). Auditor brand name reputations and industry specializations. Journal of Accounting and Economics, 20(3), 297-322.

Davis, D. (1995). Contracts for public sector audits in New Zealand, unpublished Master of Business Studies thesis, Massey University, Wellington

DeAngelo (1981). Auditor Size and Audit Quality. Journal of Accounting and Economics, 3(3), 183-199.

Duff, A. (2004), Dimension of Audit quality, University of Paisley.

Francis, J.R. (2004). What do we know about audit quality?. The British Accounting Review, 36, 345-368.

Hair, J., Black, W., Babin, B., Anderson, R., \& Tatham, R. (2006). Multivariate data analysis (6th ed.). Upper Saddle River, N.J.: Pearson Prentice Hall.

Hoang Trong \& Chu Nguyen Mong Ngoc (2008). Phân tích dĩ liệu nghiên cứu với SPSS, NXB Hong Duc.

Nguyen, H., Tham, J., Khatibi, A., \& Azam, S. (2020). Conceptualizing the effects of transfer pricing law on transfer pricing decision making of FDI enterprises in Vietnam. International Journal of Data and Network Science, 4(2), 187-198.

Nguyen, D., \& Do, D. (2020). The impact of equity in FDI firms on accountants' loyalty: Application of equity theory and creative application in economics sociological knowledge. Accounting, 6(2), 215-220.

Pandit, G.M. (1999). Clients' perceptions of their incumbent auditors and their loyalty to the audit firms: an empirical study. The Mid-Atlantic Journal of Business, 35(4), 171-188.

Parasuraman, A., Zeithaml, V. A. \& Berry, L. L. (1988). SERVQUAL: A multiple-item scale for measuring consumer perceptions of service quality. Journal of Retailing, 64(1), 12-40.

Parasuraman, A., Zeithaml, V.A., \& Berry, L.L. (1985). A conceptual model of service quality and its implications for future research. Journal of Marketing, 49(4), 41-50

Samelson, D., Lowensohn, S. \& Johnson, L. E. (2006). The Determinants of Perceived Audit Quality and Auditee Satisfaction in Local Government. Journal of Public Budgeting Accounting and Financial Management, 18(2), $139-166$.

Schroeder, M.S., Solomon, I., \& Vickery, D. (1986). Audit quality: the perceptions of audit-committee chairpersons and audit partners. Auditing: A Journal of Practice \& Theory, 5(2), 86-93

Shockley, R.A. (1982). Perceptions of audit independence: a conceptual model. Journal of Accounting, Auditing and Finance, $5,126-143$.

Tran, N. (2020). Applying 2-stage DEA model to evaluate the corporate social responsibility implementing efficiency of FDI firms. Management Science Letters, 10(11), 2491-2500.

Warming-Rasmussen, B., \& Jensen, L. (1998). Quality dimensions in external audit services - an external user perspective. The European Accounting Review, 7(1), 65-82

Zeithaml, V.A., \& Bitner, M.J. (2000), Services Marketing: Integrating Customer Focus across the Firm. Irwin McGraw-Hill, London

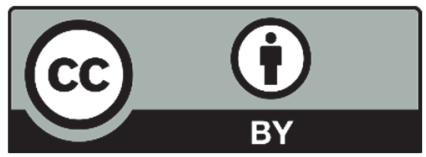

(C) 2020 by the authors; licensee Growing Science, Canada. This is an open access article distributed under the terms and conditions of the Creative Commons Attribution (CC-BY) license (http://creativecommons.org/licenses/by/4.0/). 